\title{
BODY MASS INDEX: different nutritional status according to WHO, OPAS and Lipschitz classifications in gastrointestinal cancer patients
}

\author{
Katia BARAO and Nora Manoukian FORONES
}

\begin{abstract}
Context - The body mass index (BMI) is the most common marker used on diagnoses of the nutritional status. The great advantage of this index is the easy way to measure, the low cost, the good correlation with the fat mass and the association to morbidity and mortality. Objective - To compare the BMI differences according to the WHO, OPAS and Lipschitz classification. Methods - A prospective study on 352 patients with esophageal, gastric or colorectal cancer was done. The BMI was calculated and analyzed by the classification of WHO, Lipschitz and OPAS. Results - The mean age was $62.1 \pm 12.4$ years and $59 \%$ of them had more than 59 years. The BMI had not difference between the genders in patients $\leq 59$ years $(P=0.75)$, but over 59 years the BMI was higher in women $(P<0.01)$. The percentage of undernourished was $7 \%, 18 \%$ and $21 \%(P \leq 0.01)$ by WHO, Lipschitz and OPAS, respectively. The overweight/obesity was also different among the various classifications $(P \leq 0.01)$. Conclusions - Most of the patients with gastrointestinal cancer had more than 65 years. A different cut off must be used for this patients, because undernourished patients may be wrongly considered well nourished.
\end{abstract}

HEADINGS - Body mass index. Nutritional status. Gastrointestinal neoplasms.

\section{INTRODUCTION}

Many methods are used to evaluate the corporeal composition $^{(10)}$, though only a few are applicable on large groups of individuals, as in epidemiological studies, mainly due to the elevated cost.

The body mass index (BMI) ${ }^{(1,4)}$ is the most widely used indicator in epidemiological studies, associated or not with other anthropometric variables to identification of patients at nutritional risk or obesity. The great advantage of this index is the easy way to measure, the low cost, the good correlation with the fat mass and the association to morbidity and mortality ${ }^{(2)}$.

The Quételet ${ }^{(18)}$ studies observed that in adult life, a normal-sized individual's weight was proportional to his stature squared. In 1972, this index was called body mass index (BMI), but sometimes the name of Quételet Index is still used.

Based on the risk of death, the World Health Organization (WHO) ${ }^{(11)}$, in 1998, proposed the utilization of the following cutoff points for the classification of nutritional status in adults: underweight with BMI $<18.5 \mathrm{~kg} / \mathrm{m}^{2}$, normal weight with BMI between 18.5 $24.9 \mathrm{~kg} / \mathrm{m}^{2}$, overweight with $\mathrm{BMI} \geq 25 \mathrm{~kg} / \mathrm{m}^{2}$ and obesity with $\mathrm{BMI} \geq 30 \mathrm{~kg} / \mathrm{m}^{2}$.
However the nutritional status in elderly measured by the BMI is widely discussed due to the corporeal compositions alterations $^{(5)}$. In 1994, Lipschitz ${ }^{(9)}$, studying normal adults, proposed a different cutoff for individuals over 65 years of age, being underweight individuals with less than $22 \mathrm{~kg} / \mathrm{m}^{2}$ and overweight individuals with more than $27 \mathrm{~kg} / \mathrm{m}^{2}$.

The Pan-American Health Organization (OPAS) ${ }^{(12)}$ recommends the following classification for subjects over 59 years of age: BMI less than $23 \mathrm{~kg} / \mathrm{m}^{2}$ as underweight; between 23 and $28 \mathrm{~kg} / \mathrm{m}^{2}$ as normal weight; between 28 and $30 \mathrm{~kg} / \mathrm{m}^{2}$ as overweight and more than $30 \mathrm{~kg} / \mathrm{m}^{2}$ as obesity.

Patients with gastrointestinal cancer had frequently more than 65 years and the WHO classification of the BMI can underestimate the number of patients on nutritional risk.

The aim of this study is to identify the BMI of the patients with gastrointestinal cancer and compare the percentage of patients on nutritional risk according to the classification of WHO, OPAS and Lipschitz.

\section{METHODS}

A prospective study was conducted in 352 gastro-

Oncology Group from the Gastroenterology Division, Universidade Federal de São Paulo, São Paulo, SP, Brazil.

Correspondence: Prof. Nora Manoukian Forones - Disciplina de Gastroenterologia - Universidade Federal de São Paulo - Rua Botucatu, 740, $2^{0}$ andar - 04023-900 - São

Paulo, SP, Brazil. E-mail: nora@gastro.epm.br 
intestinal cancer outpatients on treatment or follow-up at the Oncology Group of the Division of Gastroenterology at Escola Paulista de Medicina, Universidade Federal de São Paulo, SP, Brazil (EPM-UNIFESP). Patients with esophageal, gastric and colorectal cancer were included. Patients with edema or ascites were excluded.

Anthropometric measurements, i.e. weight $(\mathrm{kg})$ and height $(\mathrm{cm})$, were taken from all patients, on a Filizola 180 platform-type scale, for calculated the BMI. Statistical analysis was performed using the SPSS V16 software. The $t$ Student test was used to compare the variables between the groups. The chi-square test was used to determine whether two variables and their levels were statistically dependent. A significance level of $0.05(5 \%)$ and confidence interval $(95 \%)$ were used.

\section{RESULTS}

Among the 352 patients, $50.8 \%$ were females. The mean age was $62.1 \pm 12.4$ years and $59 \%$ of them had more than 59 years (Table 1). The patients were divided in two groups according to the age and sex. The percentage of males and females was not different in the group with $\geq 59$ years compared to the others (Table 1). The BMI had not difference between the genders in patients $\leq 59$ years $(P=0.75)$, but over 59 years the BMI was higher in women $(P<0.01)$ (Table 2$)$.

The numbers of the undernourished patients according to the WHO, OPAS and Lipschitz classifications were 7\%, 18\%,

TABLE 1. Age according to the gender of the patients

\begin{tabular}{lcccc}
\hline & $\begin{array}{c}\text { Total } \\
(\mathrm{n}=352)\end{array}$ & $\begin{array}{c}\text { Males } \\
(\mathrm{n}=173)\end{array}$ & $\begin{array}{c}\text { Females } \\
(\mathrm{n}=179)\end{array}$ & $\boldsymbol{P}$ \\
\hline$\leq 59$ years $(41 \%)$ & 144 & 67 & 77 & \\
$>59$ years $(59 \%)$ & 208 & 106 & 102 & 0.47 \\
Age $($ mean $\pm \mathrm{SD})$ & $62.1 \pm 12.4$ & $61.9 \pm 11.9$ & $62.2 \pm 12.9$ & 0.81 \\
\hline
\end{tabular}

TABLE 2. BMI (mean $\pm \mathrm{SD})$ in both genders according to the age

\begin{tabular}{cccccc}
\hline & & Total & Males & Females & $\boldsymbol{P}$ \\
\hline \multirow{3}{*}{ BMI } & $\leq 59$ ys & $25.3 \pm 5.2$ & $25.1 \pm 5.0$ & $25.4 \pm 5.3$ & 0.75 \\
& $>59$ ys & $25.6 \pm 5.2$ & $24.6 \pm 4.9$ & $26.5 \pm 5.3$ & $<0.01$ \\
& Total & $25.4 \pm 5.2$ & $24.8 \pm 5.0$ & $26.0 \pm 5.3$ & 0.04 \\
\hline
\end{tabular}

TABLE 3. Number of patients classified as undernourished, well nourished and overweight or obesity classified according to the WHO, Lipschitz and OPAS

\begin{tabular}{ccccc}
\hline & $\begin{array}{c}\text { WHO } \\
\text { n (\%) }\end{array}$ & $\begin{array}{c}\text { Lipschitz } \\
\text { n (\%) }\end{array}$ & $\begin{array}{c}\text { OPAS } \\
\text { n (\%) }\end{array}$ & $\boldsymbol{P}$ \\
\hline Undernourished & $26(7)$ & $64(18)$ & $74(21)$ & $<0.01$ \\
Well nourished & $144(41)$ & $138(39)$ & $145(41)$ & \\
Overweight/obesity & $182(52)$ & $150(43)$ & $133(38)$ & \\
\hline
\end{tabular}

BMI = body mass index;

WHO $=$ World Organization of Health;

OPAS = Organización Panamericana de la Salud
$21 \%$, respectively. This difference was significant $(P<0.01)$. The numbers of obese patients was also different in the three classifications, being higher in the WHO classification and smaller in the OPAS or Lipschitz $(P<0.01)$ (Table 3).

\section{DISCUSSION}

The easy and good correlation of the BMI with morbidity and mortality justify its use in epidemiological studies and clinical practice, in spite of it not representing the corporeal composition of individuals ${ }^{(3)}$.

Some classifications, such as the OPAS or the Lipschitz, divided the BMI by age because the corporeal composition and fat distribution vary with age $e^{(3,5,7,12,17)}$, which does not occur in the WHO classification ${ }^{(11)}$. Comparing the results found, $48(14 \%)$ were normal weight by the WHO classification, whereas they were considered undernourished by the OPAS. Furthermore, 14\% obese patients by the WHO classification were normal weight by the OPAS. This is an important factor, mainly when dealing with digestive tract cancer patients, which occurs mainly after the 6th decade of life ${ }^{(8)}$. In our sample, $59 \%$ of the group studied was over 59 years, with a mean age of $62.1 \pm 12.4$ years.

The BMI median among the undernourished patients varied using the different classifications. In the WHO classification we found the lowest BMI because the term undernourished includes only patients with a BMI $<18.5 \mathrm{~kg} / \mathrm{m}^{2}$, not including elderly patients at great risk of becoming undernourished. Age leads to nutritional transformation, mainly in fat mass and in women ${ }^{(7)}$. A research done in Brazil with 41 geriatric patients described a better correlation of MAN (Mini Nutritional Assessments) scores nutritional status using the Lipschitz then the WHO classification ${ }^{(13)}$.

As undernourishment has been recognized as a condition associated with an increased risk of infectious complications after surgery, mainly in elderly, it is necessary the diagnosis of these patients ${ }^{(15)}$. It is not clear the total mechanism responsible to the correlation between undernourishment and adverse clinical effects, but it is probably a combination of immune, inflammatory and metabolic processes ${ }^{(6,16)}$.

This study had shown a difference among the various classifications of the nutritional status. Among the 352 patients analyzed, $14 \%$ of them had differences on interpretation according to the classification used. These results are useful to indicate the necessity to alert the health professionals to use specific measures for elder patients.

According to Stevens et al. ${ }^{(15)}$, the choice of the BMI cutoffs may have a political impact because they are used to evaluate the population's health and the necessity for health-promoting measures. Nevertheless, for health professionals, the use of a BMI with different cutoff points for patients over 59 years of age is important, as it would take into account the corporeal modifications which occur with aging and in this way permit a more precise diagnosis of the nutritional status for this age bracket. Other methods, such as the subjective global evaluation and the nutritional risk ${ }^{(14)}$, 
may assist in the detection of undernourishment at an earlier stage than the BMI, but they are not did commonly by physicians. Most of time these questionnaires were applicated by nutritionists that are not always present in the treatment of oncologic outpatients.

The present study showed the variation in the results of the different cutoff points of the BMI, highlighting the importance of an adjustment for the group studied. Most of the patients with gastrointestinal cancer had more than 65 years. A different cutoff must be used for this patients, because undernourished patients may be wrongly considered well nourished. The early detection of undernourishment and its correction may assist in the treatment of the disease and the prevention of complications.

\section{ACKNOWLEDGMENTS}

This study was supported by FAPESP (São Paulo Research Foundation 08/10001-6). The authors thank the volunteers who participated in this cross-sectional study.

Barao K, Forones NM. Índice de massa corpórea: estados nutricionais divergem de acordo com as classificações de WHO, OPAS e Lipschitz em pacientes com câncer gastrointestinal. Arq Gastroenterol. 2012;49(2):169-71.

RESUMO - Contexto - O índice de massa corpórea (IMC) é largamente usado no diagnóstico do estado nutricional. As principais vantagens deste índice são a facilidade de obtenção, o baixo custo e a correlação com o índice de massa gorda. Objetivo - Comparar as diferenças entre o IMC de acordo com as classificações da OMS, OPAS e Lipschitz. Método - Foi realizado estudo prospectivo com 352 pacientes com câncer esofágico, gástrico ou colorretal. O IMC foi calculado e analisado pelas classificações da OMS, de Lipschitz e da OPAS. Resultados - A média de idade foi de 62,1 \pm 12,4 anos e $59 \%$ dos pacientes tinham mais que 59 anos. O IMC não variou entre os sexos nos pacientes com idade $\leq 59$ anos $(P=0,75)$, mas após os 59 anos o IMC foi maior entre as mulheres $(P<0,01)$. O percentual de desnutridos foi de $7 \%, 18 \%$ e $21 \%(P \leq 0,01)$ segundo as classificações da OMS, Lipschitz e OPAS, respectivamente. O sobrepeso/obesidade também diferiu entre as várias classificações $(P \leq 0,01)$. Conclusões - Os pacientes com câncer gastrointestinal têm com frequência idade superior a 65 anos. Um diferente nível de corte deve ser usado para estes pacientes porque os desnutridos podem ser erroneamente considerados bem nutridos.

DESCRITORES - Índice de massa corpórea. Estado nutricional. Neoplasias gastrointestinais.

\section{REFERENCES}

1. Allison DB, Zhu SK, Plankey M, Faith MS, Heo M. Differential associations of body mass index and adiposity with all-cause mortality among men in the first and second National Health and Nutrition Examination Surveys (NHANES I and NHANES II) follow-up studies. Int J Obesity. 2002;26:410-6.

2. Anjos LA. Índice de massa corporal como indicador do estado nutricional de adultos: revisão da literatura. Rev Saúde Pública. 1992;26:431-6.

3. Cervi A, Franceschini SCC, Priore SE. Critical analysis of the use of the body mass index for the elderly. Rev Nutr. 2005;18:765-75.

4. Deurenberg P, Kooy K, Hulshof T, Evers P. Body mass index as a measure of body fatness in the elderly. Eur J Clin Nutr. 1989;43:231-6.

5. Garrow JS. Three limitations of the body mass index. Am J Clin Nutr. 1988;47:553

6. Heys SD, Schofield AC, Wahle KW, Garcia-Caballero M. Nutrition and the surgical patient: triumphs and challenges. Surgeon. 2005;3:139-44. doi: 10.1016/ S1479-666X(05)80033-2.

7. Jackson AS, Stanforth PR, Gagnon J, Rankinen T, Leon AS, Rao DC, et al. The effect of sex, age and race on estimating percentage body fat from body mass index: The Heritage Family Study. In J Obesity. 2002; 26:789-96.

8. Jemal A, Siegel R, Xu J, Ward E. Cancer statistics, 2010 CA. Cancer J Clin 2010;60:277-300 doi: 10.3322/caac.20073. Downloaded from caonline.amcancersoc.org by on Aug 10, 2011.

9. Lipschitz DA. Screening for nutritional status in the elderly. Prim Care. 1994;21:55-67.
10. Lukaski HC. Methods for the assessment of human body composition: traditional and new. Am J Clin Nutr. 1987;46:537-56.

11. Organización Mundial de la Salud. El estado físico: uso e interpretación de la antropometría. Genebra: OMS; 1995. p.452. (OMS, Serie de Informes Técnicos, 854).

12. Organização Pan-Americana (OPAS). XXXVI Reunión del Comité Asesor de Investigaciones en Salud - Encuestra Multicêntrica - Salud Bienestar y Envejecimiento.(SABE) en América Latina e el Caribe - Informe preliminar [Internet]. [cited Mar. 2002]. Available from: http://www.opas.org/program/sabe.htm.>

13. Paula HAA, Oliveira FCE2, Jose JFBS, Gomide CI, Alfenas RC. Avaliação do estado nutricional de pacientes geriátricos. Rev Bras Nutr Clin. 2007;22:280-5.

14. Ryu SW, Kim IH. Comparison of different nutritional assessments in detecting malnutrition among gastric cancer patients. World J Gastroenterol. 2010;16:3310-7.

15. Stevens J, Juhaeri, Cai J, Jones DW. The effect of decision rules on the choice of a body mass index cutoff for obesity: examples from African American and white women. Am J Clin Nutr. 2002;75:986-92.

16. Warnold I, Lundholm K. Clinical significance of preoperative nutritional status in 215 noncancer patients. Ann Surg. 1984;199:299-305.

17. Weigley ES. Adolphe Quetelet (1796-1874): pioneer anthropometrist. Nutr Today. 1989;24(2):12-6

Received 20/10/2011. Accepted 24/1/2012. 